\title{
Investigating causes and consequences of purchase intention of luxury fashion
}

\author{
Suha Fouad Salema ${ }^{a^{*}}$ and Kamelia Chaichi ${ }^{\mathrm{b}}$
}

${ }^{a}$ Faculty of Business Management and Professional Studies, Management and Science University, Malaysia ${ }^{b}$ School of Hospitality and Tourism, Sunway Unversity, Malaysia

\begin{tabular}{|c|c|}
\hline CHRON I C L E & A B S T RACT \\
\hline $\begin{array}{l}\text { Article history: } \\
\text { Received: August } 2,2018 \\
\text { Received in revised format: Au- } \\
\text { gust } 30,2018 \\
\text { Accepted: October } 1,2018 \\
\text { Available online: } \\
\text { October } 1,2018 \\
\text { Keywords: } \\
\text { Luxury fashion } \\
\text { Self-identity } \\
\text { Price premium } \\
\text { Theory of planned behavior } \\
\text { Malaysia }\end{array}$ & $\begin{array}{l}\text { The purpose of this study is to examine the influences of self-identity, subjective norm and attitude } \\
\text { on the intention to purchase luxury fashion goods. It also demonstrates how purchase intention } \\
\text { influences on customers' intention to pay premium prices for luxury fashion goods. A theoretical } \\
\text { model is established and assessed in this study on a sample of luxury fashion consumers in Malay- } \\
\text { sia. By means of a self-structured questionnaire, } 240 \text { valid submissions are included for data anal- } \\
\text { ysis with the Smart-PLS software } 3.2 .0 \text {. The results support all hypotheses on the correlation of } \\
\text { self-identity, subjective norm and attitude with purchase intention and price premium, except the } \\
\text { correlation between self-identity and purchase intention. This is the first research paper investigat- } \\
\text { ing self-identity as an antecedent of purchase intention, and price premium as a consequence of } \\
\text { purchase intention. It also justifies the behavior of luxury fashion consumers with regards to luxury } \\
\text { fashion products. Findings from this study may help marketers develop effective strategies which } \\
\text { would yield them a competitive advantage within the luxury fashion market. }\end{array}$ \\
\hline
\end{tabular}

\section{Introduction}

The demand for luxury brand products has experienced a worldwide growth rate of 7\% from 1995 to 2013, which is expected to increase even more at an annual rate of 4 or 5\% until 2020 (Kapferer \& Laurent, 2016). Recently, international luxury fashion homes have shown a solid interest in the market in Malaysia, as most leading luxury fashion brands have opened up stores in among other places, SuriaKLCC, Pavilion, Starhill Gallery, The Gardens and Johor Premium Outlet (Euromonitor International, 2016). Consumer involvement in the recently-expanding Malaysian luxury market is expected to become more widespread due to lifestyle changes, as Malaysians begin to spend more and more on luxury goods (McColl \& Moore, 2011). Official statistics revealed that the total retail sales in Malaysia hit 33.6 billion ringgit in July 2016, following an increase of 9.4\% over the course of one year (Department of Statistics Malaysia, 2016). For this reason, an investigation of the variables encouraging customers to buy luxury goods has valuable managerial and theoretical contributions, especially to marketers (Chiu \& Leng, 2016). From these findings, marketers may develop effective strategies to gain customers and enhance customer loyalty, an important aspect in the long-term, and cater to the increase in demands for luxury

* Corresponding author.

E-mail address: suha fksalem@msu.edu.my (S.F. Salem) 
fashion goods (Soh et al., 2017). A deeper understanding of consumers will provide companies with a competitive advantage in the luxury fashion market (Keller \& Kotler, 2016).

One characteristic of luxury products is price premium, which is critical for businesses to sustain in a competitive market (Anselmsson et al., 2014). According to Ailawadi et al. (2003), price premium is an indicator of brand power and strength, as price premium is an achievement after many years of stability in a competitive market. Although price premium is an essential trait of a successful brand, empirical studies on the factors motivating customers to pay price premium are scarce (Anselmsson et al., 2014).Furthermore, it has been demonstrated by prior studies that an individual's identity can be used to predict customer engagement and behaviour (Coelho et al., 2018; Maria \& Brandão, 2017). This research paper implements the Theory of Planned Behaviour (TPB) to analyse elements affecting customers' disposition towards price premium. In the luxury sector, literature on marketing and on consumer behaviour has already studied behavioural intentions (Mamat et al., 2016; Wu et al., 2015) and buying behaviour (Zhan \& He, 2012; Soh et al., 2017). Yet not enough studies have examined the effect of self-identity on behavioural intention and other factors such as subjective norm, attitude, self-identity and behavioural intention on whether consumers actually pay the price premium for goods in Malaysia (Anselmsson et al., 2014; Wu et al., 2015). This paper is meant to fill in such gaps via the inclusion of self-identity and price premium to the Theory of Planned Behaviour. Hence, the research objective is to investigate how self-identity, attitude and subjective norm influence customers' behavioural intentions and how these affect their contentment with premium-priced luxury fashion items in Malaysia. In the following section, the theories behind the paper shall be discussed, alongside the process by which the proposed model was created, and the hypotheses, discussion, implications, limitations and recommended direction for future research.

\section{Literature review}

\subsection{Luxury Fashion}

The discussion of luxury versus non-luxury products is driven normally by premium characteristics that distinguish the two broad categories (Heine, 2010). Luxury products are known for their high price, high quality, high aesthetics, their rarity, their extraordinariness, and the symbolism of their products (Sjostrom et al., 2016). Berthon et al. (2009) suggested the characteristics of luxury goods are to be categorised into three dimensions: functional, experiential, and symbolic, that correspond to the three spheres, which are material, individual, and social. One of the early definitions of luxury products is the relationship between their functional value, their price value and their intangible and situational value, which oversees their intangible and situational value as consistently higher than their functional value when the latter is associated with their price (Nueno \& Quelch, 1998). Shukla et al. (2009) argued that non-luxury products appeal to consumers because of their functionality, unlike luxury products which appeal to consumers because of their experiential and symbolic values. It is evident that goods in general have a prominent role in the satisfaction of socio-psychological needs in humans.

The luxury fashion products domain extends to apparel, shoes, underwear, as well as other accessories such as belts, scarfs, ties, eyewear, bags and wallets (Heine, 2010). Depending on the scholar, there may be slight differences in the domain, regarding the inclusion or exclusion of items such as perfume and jewellery (Vigneron \& Johnson, 2004). Based on the 2016 report of Euro monitor International, the active international luxury houses in Malaysia are LVMH, Prada, Kering, PVH, Luxottica and Burberry, offering Louis Vuitton, Gucci, Prada, Calvin Klein, Burberry and Emporio Armani.

In Asia and specifically in Malaysia, the sale of luxury goods is expected to rise (Soh et al., 2017). This expansion of the Malaysian luxury market is expected to impact consumers' lifestyles (Euromonitor International, 2016). During the latest years, there has been an increase in the consumers' income, leading to a subsequent increase in their demand for luxury fashion goods (Vijaranakorn \& Shannon, 2017). Moreover, retail sales in Malaysia have recorded a total of 33.6 billion in July 2016, which is a $9.4 \%$ 
increase since July 2015 (Soh et al., 2017). In Malaysia, there are a number of international fashion brands located in shopping malls, indicating that Malaysian consumers tend to shop for branded goods (Ashraf, 2017).

\subsection{Research Hypotheses}

Luxury fashion goods have a symbolic value that, when this corresponds to the consumers' self-identity, it will motivate them to purchase these products. It has been argued that individual behaviour is affected by self-image and personality (Sirgy, 1986). Choo et al. (2012) argue that self-expression is provided by the symbolic value of a product. Kauppinen-Räisänen et al. (2014) stated that one must note that luxury fashion purchase is often self-oriented, as consumers tend to self-gift themselves. Soh et al. (2017) investigated luxury fashion purchase behaviour among 384 generation $\mathrm{Y}$ consumers and proved that the need for uniqueness influences the consumer's purchase intention. The correlation between self-identity and consumers' purchase intention regarding organic cotton apparel was examined and demonstrated by Hustvedt and Dickson (2008). In their study on fashion buying behaviour among generation, Valae and Nikhashemi (2017) proved a considerable correlation between self-identity and purchase intention. The outcome of self-identity on different constructs of TPB has been examined in numerous studies. Fashion reflects the personality and behaviour of an individual (Valae \& Nikhashemi, 2017). Consumers buy luxury fashion products to have in their possession an item of a symbolic value that relates to their identity (Michaelidou \& Dibb, 2006). Moreover, in a study by Khallouli and Gharbi (2013) a person's belief concerning his/her capability to exhibit a specific behaviour is shaped by the self-expression, which leads to form specific self-identity. De Mooij (2010) indicated that when people have a clear identity, they are motivated to exploit available resources including money, time and effort to purchase products that reflect their own identity, regardless of how high the price is.

Maloney et al. (2014), Han and Stoel (2016) and Kong and Ko (2017) argued that when products reflect their identity and personality, their positive perception of this product might enhance their disposition to pay the high price. Therefore, it is assumed that self-identity will improve customer disposition towards paying premium prices and thus, their purchase intention of the product.

\section{H1: Self-identity increases a customer's will to pay premium price.}

H2: Self-identity enhances a customer's purchase intention.

Attitude and subjective norm are the determinants of the TPB model by Ajzen (1991). Hsu et al. (2017) demonstrated that TPB is the most reliable model predicting social behaviour. According to Ajzen, (1985) behavioural intention is influenced by subjective norm and attitude and carves actual behaviour. Attitude towards behaviour is equivalent to belief that a specific behaviour causes a specific outcome (Ajzen \& Fishbein, 1980). Further, Ajzen and Fishbein (1980) defined subjective norm as the extent to which important people influence individual behaviour. Perceived behavioural control is the belief in one's ability or inability to exhibit a behaviour, which has control over the actual behavioural performance (Ajzen, 1991). In a study of luxury fashion goods in India, Jain and Khan, (2017) examined consumer behaviour, based on the TPB, and data suggests that attitude and subjective norm are the antecedents for purchase intention. In another study, Cheah et al. (2015) examined consumers' attitude towards buying high-price luxury fashion apparel made in sweatshops and the findings indicate that a feeling of comfort towards a certain brand causes consumers to pay premium price even when options for lower prices are available. Moreover, Han and Stoel (2016) have also proven the correlation between attitude and the intention to buy premium cotton apparel. In other words, and in most TPB literature, that all TPB elements, for instance attitude and subjective norm, considerably influence consumers' purchase intention, is fully supported (Chen \& Tung, 2014; Timperio et al., 2016; Hsu et al., 2017). Therefore, it can be hypothesised as below:

H3: Attitude towards luxury fashion affects customers to buy luxury fashion.

H4: Attitude towards luxury fashion affects disposition towards paying premium prices. 
H5: Subjective norm affects intention to buy luxury fashion.

H6: Subjective norm affects disposition towards paying premium prices.

Price premium intention is the extent of willingness of a buyer to pay for an item, without its price affecting his decision (Zhang \& Kim, 2013). Hultman et al. (2015) combined TPB theory with price premium to examine the consumers' disposition towards price premium for ecotourism. The study concluded the strongest predictor of consumers paying premium price is intention. Wu et al., (2015) in a qualitative study argued that price premium has a role in explaining involvement in luxury fashion. Stallmeadows and Davey (2015) examined different dimensions of attitude association with price premium of premium green apparel. The role of price premium on influencing green apparel purchases was supported. Although it is uncommon to examine price premium as the outcome variable in luxury fashion, several studies have proven the importance of its inclusion in the understanding of this field. Therefore, it is important to assess whether the solid intention to buy luxury products will affect the reaction to price premium.

\section{H7: Intention to buy luxury fashion enhances disposition towards price premium.}

On the basis of discussions in literature thus far, our paper proposes a model presented in Fig. 1. The model comprises a construct of five variables, in which purchase intention and price premium are the outcome variables.

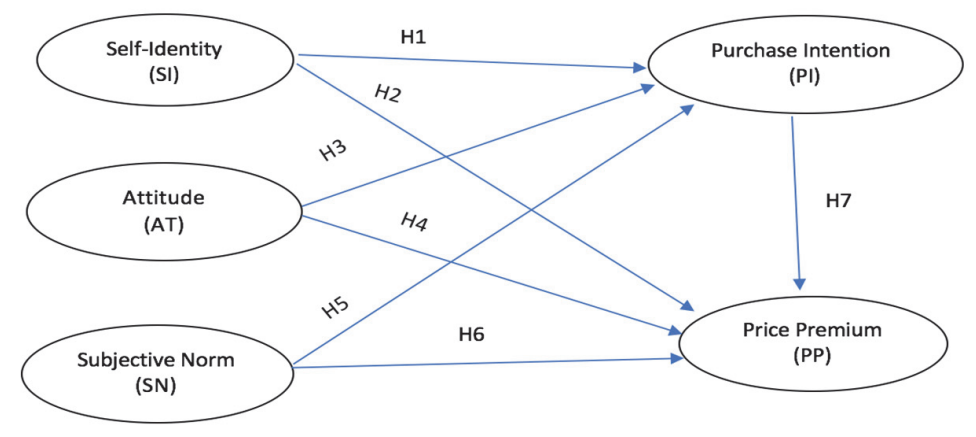

Fig. 1. A conceptual framework

\section{Research method}

This study follows the scientific approach, starting with a hypothesis and ending with a quantitative analysis of the hypothesis. Therefore, this study employs a quantitative approach and is a deductive type of research, which uses a questionnaire and variance-based statistical analysis (Structural Equation Modelling).

\subsection{Population, Sampling, and Data Collection}

The target participants of this paper are luxury fashion clients in Kuala Lumpur, Malaysia. Kuala Lumpur (also pronounced KL) is the capital of Malaysia; the city hosts a wide variety of active international luxury brands, such as Louis Vuitton, Gucci, Prada, Calvin Klein, Burberry and Emporio Armani (Euromonitor International, 2016). Most potential luxury fashion consumers are either living in KL or visiting KL. Therefore, to reach these target participants, non-probability sampling techniques are used due to the unequal chance of selecting the individual within the population (Statpac, 2014). The reason for selecting this technique is the size of the population and the difficulty to identify customers' traits via statistical inference (Bryman \& Bell, 2007). To distribute the survey questionnaire, the purposive sampling method is adopted. The samples are easy to reach time and location-wise (Bryman \& Bell, 2007). Data is collected by trained facilitators via face-to-face communication with potential consumers shopping in Pavillion, Suria-KLCC, and The Gardens malls. Micro-locations of data collection spots are the 
stand-alone stores of leading luxury brands in Malaysia: Louis Vuitton, Gucci, Prada, Calvin Klein, Burberry and Emporio Armani, which are located inside the three luxury malls. In order to collect data from these malls, clients were localised departing luxury fashion retailers after purchasing from these retailers and also purchased luxury fashion products, mainly bags, apparel, shoes, underwear, and accessories, in the last five years. This 5-year duration is necessary to confirm that customers are experienced with these luxury fashion products. This approach is an accepted method of accessing potential consumers (Zhan \& $\mathrm{He}, 2012)$. Once they have been identified, the potential consumer is requested to complete the survey and contribute to the academic work. The potential participants invited to complete the survey were 520, whereas the actual participants who agreed to fill in the questionnaire were 350 . After filtering incomplete questionnaires, the valid samples for proceeding were 240. Data was collected from March to April 2017.

According to Hair et al. (2011), sample size can be considered effective when the size ranges between 30 to 500 . We have used power analysis to identify sample size and SEM models suggested by Hair Jr et al. (2016). The current study was based on prior-sample size calculations from Structural Equation Models (SEM) as applied by Westland (2010). This study calculated the sample size using the number of measurement categories, of exogenous and endogenous elements as input data (Westland, 2010). The recommended sample size was 112 based on the input data (number of observed variables $=19$, statistical power $=95 \%$ and probability level $=0.05$ ). According to the aforementioned justifications, the sample size required for the method can easily be achieved.

\subsection{Questionnaire}

The tool for data collection is a self-directed questionnaire with closed-ended questions based on the Likert-5 coding technique. The questionnaire was written in English and translated into Malay, the main language in Malaysia. Translation process was undertaken by a professional translator well-versed in the subject, according to a process recommended by Adler (1983). However, the respondents were given the choice between English and Malay to complete the questionnaire, which consisted of two parts: i) respondents' demographic information and ii) respondents' opinions. Demographic information comprises gender, age, qualification, marital status, income, and occupation. Information dealt with purchase intention was based on the three elements adapted from Ajzen and Fishbein, (1980) and Madden et al. (1992) and five items from Loureiro and Araújo (2014) and Zhan and He (2012) to assess respondents' attitude towards luxury behaviour. Subjective norm depended on four elements from Ajzen and Fishbein (1980) and Fitzmaurice (2005). The measurement for self-identity uses the same four items used by Loureiro and Araújo (2014) and Wiedmann et al. (2009). Finally, the measurement for price premium construct uses the same three items as used by Li et al. (2013) and Bang et al. (2000).

\subsection{Common Method Bias (CMV)}

This paper assessed common method variance before it proceeded to PLS-SEM analysis. According to Spector (2006), CMV may accrue in quantitative research as well as when data collection is from one source (MacKenzie \& Podsakoff, 2012). This research follows Harman's (1976) one-factor test and Bagozzi's method, (Bagozzi, Yi, \& Phillips, 1991) to identify the potential threat of CMV. The SPSS software is used to apply Harman's one-factor test and results indicate the absence of a CMV issue. According to Bagozzi's method, CMV is an issue when any two variables have a correlation higher than 0.9 (Bagozzi et al., 1991). Table 3 determines the highest correlation as 0.780 that is the correlation between attitude and purchase intention. Therefore, no CMV issue is present in the data used.

\subsection{Structural Equation Modelling (SEM)}

Although the SEM technique includes several statistical methods that enable researchers to improve and verify models and theories (Anderson \& Gerbing, 1982), a preferable technique is to test hypotheses and evaluate parameters (Fornell \& Larcker, 1981; Hair et al., 2011). In SEM and according to, VB-SEM 
and convenience-based SEM (CB-SEM) rely on a theory. Reinartz et al. (2009) argued that CB-SEM is particular with errors and sets of model parameters whereas PLS-SEM delegates scholars to question the causal relationship between latent constructs and the causal relationship between items (Rezaei, 2015). To add on, when the objective is to expand upon the extant structural theory, PLS-SEM is preferable over CB-SEM (Hair et al., 2011). Furthermore, Henseler et al. (2014) and Hair et al. (2011) suggest PLSSEM as a preferred technique when the central purpose is accurate prediction in a complex model with many indicators and constructs. Therefore, this study considers PLS-SEM method as the most suitable approach for analysis based on the aforesaid justifications, as well as because of the complexity of the proposed model as it includes 7 paths and two dependent variables (Ringle et al., 2012). PLS-SEM analysis includes two processes which are to assess the inner model (measurement model) and to assess the outer model (structural model) (Henseler, 2010). The measurement model evaluates the relationship between indicators and validates constructs, whereas the structural model assesses the relationship between constructs (hypothesis testing) (Anderson \& Gerbing, 1982). In our present study, PLS-SEM analysis is evaluated by SmartPLS software.

\section{Findings}

\subsection{Descriptive Analysis on Sample Profile}

As in Table 1, the final sample of respondents comprises 240 samples. The majority of respondents are identified by the following categories with the following statistics: $57.1 \%$ are females, $42.9 \%$ aged between 36 and 45, 42.9\% have their own business, and $81 \%$ have a household income higher than RM4000.

Table 1

Sample Profile

\begin{tabular}{llll}
\hline & Characteristics & Frequency & Percentage \\
\hline Gender & Female & 137 & 57.1 \\
& Male & 103 & 42.9 \\
\hline Age(years) & $17-25$ & 15 & 6.2 \\
& $26-35$ & 90 & 37.6 \\
& $36-45$ & 120 & 50 \\
& Above 45 & 15 & 6.2 \\
\hline Household Income & Less than 3000 RM & 21 & 8.6 \\
& $3000-4000 \mathrm{RM}$ & 25 & 10.4 \\
& $4001-5000 \mathrm{RM}$ & 124 & 51.7 \\
& $5001-6000 \mathrm{RM}$ & 30 & 12.6 \\
& More than 6000 RM & 40 & 16.7 \\
\hline \multirow{2}{*}{ Work status } & Non-employed & 10 & 4.1 \\
& Part-time work & 15 & 6.2 \\
& Full-time work & 90 & 37.6 \\
& My own business & 103 & 42.9 \\
& Other & 22 & 9.2 \\
\hline
\end{tabular}

\subsection{Validity and Reliability of Constructs}

Several measures have been conducted, such as composite reliability, outer loading, convergent validity, and discriminant validity to confirm reliability and validity of the measurement model (Hair et al., 2011; Sekaran, 2006). As in Table 2, the Cronbach's Alpha and composite reliability values pass the cut-off value, which is 0.70 . Therefore, the measurement model is reliable. In addition, no multicollinearity has been found to exist as the VIF values are within the valid measure, which is between 0.2 and 5.0. Outer loading for all the items is above 0.708 with no cross loading from foreign items, so the indicator reliability is achieved. The Average Variance Extracted (AVE) values are higher than 0.5, meaning that the convergent validity is achieved as well. 
Table 2

Construct Reliability and Validity

\begin{tabular}{|c|c|c|c|c|c|c|}
\hline construct & Item & Loading & AVE & VIF & Cronbach's alpha & $\begin{array}{l}\text { Composite } \\
\text { Reliability } \\
\end{array}$ \\
\hline \multirow{4}{*}{$\begin{array}{l}\text { Self-Identity } \\
\text { (SFI) }\end{array}$} & SI1 & 0.783 & \multirow{4}{*}{0.632} & 1.686 & \multirow{4}{*}{0.807} & \multirow{4}{*}{0.873} \\
\hline & SI2 & 0.746 & & 1.598 & & \\
\hline & SI3 & 0.835 & & 1.852 & & \\
\hline & SI4 & 0.812 & & 1.667 & & \\
\hline \multirow{5}{*}{$\begin{array}{l}\text { Attitude Towards Purchas- } \\
\text { ing (AP) }\end{array}$} & AT1 & 0.812 & \multirow{5}{*}{0.720} & 1.993 & \multirow{5}{*}{0.903} & \multirow{5}{*}{0.928} \\
\hline & AT2 & 0.852 & & 2.483 & & \\
\hline & AT3 & 0.880 & & 2.870 & & \\
\hline & AT4 & 0.874 & & 2.795 & & \\
\hline & AT5 & 0.823 & & 2.163 & & \\
\hline \multirow{4}{*}{ Subjective Norm (SN) } & SN1 & 0.841 & \multirow{4}{*}{0.703} & 2.253 & \multirow{4}{*}{0.859} & \multirow{4}{*}{0.904} \\
\hline & SN2 & 0.868 & & 2.426 & & \\
\hline & SN3 & 0.856 & & 2.356 & & \\
\hline & SN4 & 0.786 & & 1.939 & & \\
\hline \multirow{3}{*}{$\begin{array}{l}\text { Price Premium } \\
\text { (PP) }\end{array}$} & PP1 & 0.835 & \multirow{3}{*}{0.744} & 1.656 & \multirow{3}{*}{0.828} & \multirow{3}{*}{0.897} \\
\hline & PP2 & 0.886 & & 2.253 & & \\
\hline & PP3 & 0.865 & & 2.032 & & \\
\hline \multirow{3}{*}{ Purchase Intention (PI) } & PI1 & 0.908 & \multirow{3}{*}{0.805} & 2.591 & \multirow{3}{*}{0.879} & \multirow{3}{*}{0.925} \\
\hline & PI2 & 0.893 & & 2.433 & & \\
\hline & PI3 & 0.890 & & 2.274 & & \\
\hline
\end{tabular}

Table 3

Discriminant validity - Fornell-Larcker criterion

\begin{tabular}{lccccc}
\hline \multicolumn{1}{c}{ Construct } & PI & SN & AT & PP & SI \\
\hline Purchase Intention & $\mathbf{0 . 8 9 7}$ & & & & \\
Subjective Norm & 0.755 & $\mathbf{0 . 8 3 8}$ & & & \\
Attitude & 0.78 & 0.7 & $\mathbf{0 . 8 4 9}$ & $\mathbf{0 . 8 6 3}$ & \\
price Premium & 0.737 & 0.768 & 0.719 & 0.576 & $\mathbf{0 . 7 9 5}$ \\
Self-Identity & 0.514 & 0.475 & 0.531 & \\
\hline
\end{tabular}

Table 4

Discriminant validity (heterotrait-monotrait ratio of correlations, HTMT criterion.

\begin{tabular}{lcccc}
\hline & Original Sample $(\mathrm{O})$ & Sample Mean $(\mathrm{M})$ & $2.5 \%$ & $97.5 \%$ \\
\hline $\mathrm{PI} \rightarrow$ PP & 0.75 & 0.75 & 0.68 & 0.81 \\
$\mathrm{SN} \rightarrow$ PI & 0.73 & 0.73 & 0.64 & 0.81 \\
$\mathrm{SN} \rightarrow$ PP & 0.74 & 0.74 & 0.67 & 0.81 \\
$\mathrm{AT} \rightarrow$ PI & 0.53 & 0.53 & 0.43 & 0.64 \\
$\mathrm{AT} \rightarrow$ PP & 0.76 & 0.76 & 0.67 & 0.83 \\
$\mathrm{SI} \rightarrow$ PI & 0.76 & 0.76 & 0.67 & 0.86 \\
$\mathrm{SI} \rightarrow$ PP & 0.71 & 0.71 & 0.62 & 0.79
\end{tabular}

Note: AT (Attitude Towards Purchasing), PI (Purchase Intention),, SN (Subjective Norm), PP (Price Premium), SI (Self- Identity).

Last but not least, Table 3 shows the matrix of the Fornell-Larcker criterion, indicating that there are no discriminant validity problems. Furthermore, this research uses the Monotrait heterotrait of correlations (HTMT) ratio advised by Henseler et al. (2015) to assess the discriminant validity. Henseler et al. (2015), state that discernment validity holds when HTMT confidence intervals do not contain. Table 4 shows that there is no ratio value of HTMT containing 1, which means discriminant validity holds. This study satisfies the rule of thumb proposed by Henseler et al. (2015) and Hair Jr et al. (2016).

\subsection{Structural Model}

To assess the power of the model to predict the outcome variables, predictive power $\mathrm{R}^{2}$ and predictive relevance were used (Hair Jr et al., 2016). Fig. 2 shows the causal relationships among model variables 
after running the PLS-SEM algorithm. It can be seen that predictive power $\mathrm{R}^{2}$ of price premium is 0.693 and that predictive power of purchase intention is 0.699. Meanwhile, predictive relevance Q2 of price premium is 0.48 and of purchase intention is 0.52 .

Written in Table 5 are the hypothesized relationship outcomes. This table shows that the seven research hypotheses are supported with the exception of H1. The threshold for accepting or rejecting any hypothesis is the T-statistics value, which is supposed to be more than 1.96. H1 states the relationship between self-identity and purchase intention is positive but is rejected (T-value of 1.887, path coefficient of 0.082 ). $\mathrm{H} 2$ proposes a positive relation between self-identity and price premium is validated ( $\mathrm{T}$-value of 2.693 and path coefficient of 0.185 ). $\mathrm{H} 3$ and H4, proposing the positive relationships of attitude with purchase intention and price premium, are supported with T-values of 7.689 and 2.463, and path coefficients of 0.462 and 0.191 . H5 and H6, which propose the positive relationship of subjective norm with both purchase intention and price premium, are validated by T-values above 1.96 (T-values of 7.040 and 6.112, and path coefficients of 0.392 and 0.406). Finally, as in Fig. 2, H7 confirms a positive relationship between purchase intention and price premium thanks to T-statistic of 2.574 and path coefficient of 0.186 . These findings are very important in understanding consumer behaviour toward luxury-fashion.

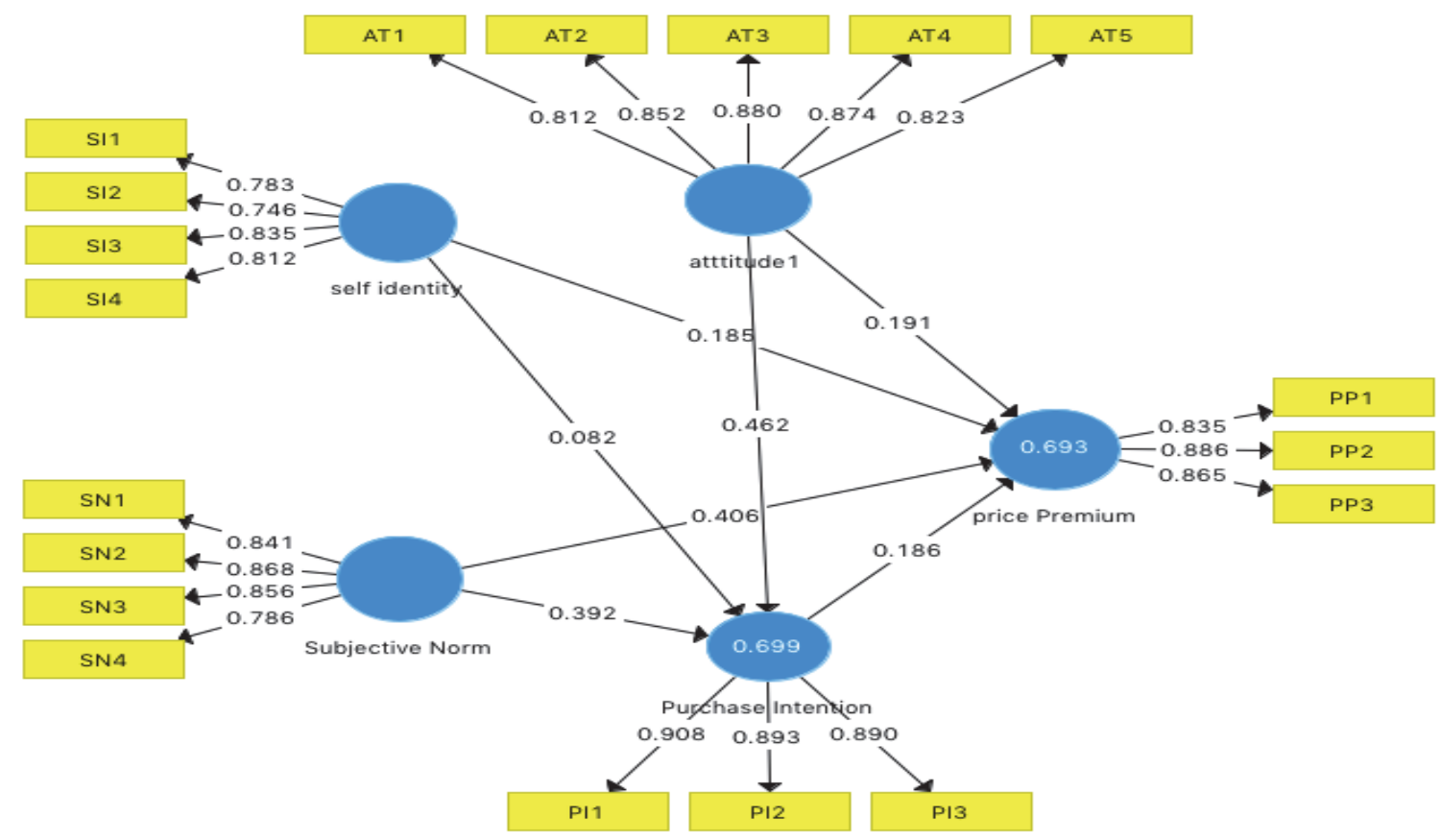

Fig. 2. PLS Algorithm Path Model

Table 5

Structural Relationships and Hypothesis Testing

\begin{tabular}{clllll}
\hline Hypothesis & Path & Path coefficient $(\boldsymbol{\beta})$ & T Statistics & P Values & Decision \\
\hline H1 & SI $\rightarrow$ PI & 0.082 & 1.887 & 0.060 & Not Supported \\
H2 & SI $\rightarrow$ PP & 0.185 & $2.693^{* * *}$ & 0.007 & Supported \\
H3 & AT $\rightarrow$ PI & 0.462 & $7.689^{* * *}$ & 0.000 & Supported \\
H4 & AT $\rightarrow$ PP & 0.191 & $2.463^{* *}$ & 0.014 & Supported \\
H5 & SN $\rightarrow$ PI & 0.392 & $7.040^{* * *}$ & 0.000 & Supported \\
H6 & SN $\rightarrow$ PP & 0.406 & $6.112^{* * *}$ & 0.000 & Supported \\
H7 & PI $\rightarrow$ PP & 0.186 & $2.574^{* *}$ & 0.010 & Supported \\
\hline
\end{tabular}

*t-values: $1.65(10 \%) ; * * t$-values: $1.96(5 \%) ; * * *$-values: $2.58(1 \%)$

Note: AT (Attitude Towards Purchasing), PI (Purchase Intention), SN (Subjective Norm), PP (Price Premium), SI (Self- Identity) 


\section{Discussion}

The objective of this paper is to investigate the role of self-identity as an external variable in the TPB and to explore price premium as one of the outcomes of behavioural intention to buy luxury fashion items.

Results indicate that self-identity enhances customer's disposition towards premium price and this is backed by the self-congruity theory indicating clients likely develop positive ideas and perceptions about brands congruent to their self-concept (Ha \& Janda, 2012; Sirgy et al., 1991). Moreover, clients locating the luxury fashion product of their interest and matching their personality and identity will start to develop beliefs that motivate them to pay a high price (Ha \& Janda, 2012). Marketers could apply campaigns that highlight the value of their brand which reflects the identity of the target market in order to create positive feelings and beliefs that will encourage customers to pay higher prices for the products (Shin et al., 2016). However, the hypothesised relationship between self-identify and behavioural intention is eliminated contrary to the results of Singh and Sanjay (2009) who discovered that when a brand personality matches an individual's identity a positive perception and attitude towards the brand product develops. Positive attitude can also be associated with purchase intention of most products (Schade et al., 2016). Nevertheless, the study shows that although self-identity can motivate the consumer to pay higher prices for luxury products, it cannot influence intention to buy the product because of the nature of the product, which is considered high-involvement products. Thus, consumers would be making the decision to accept the high prices and purchase the product, rather than to consider whether to purchase when they do find the luxury product that reflects their identity.

In addition, our research reveals attitude consolidates purchase intention and consumers' disposition towards premium price. These findings are consistent with Jain and Khan's (2017) findings, which reveal that attitude affects purchase intention in an emerging market. Yet in the aforesaid authors' findings, attitude towards buying behaviour was investigated with regards to low-involvement products. As mentioned earlier, if consumers form a favourable attitude towards high-involvement products, this might motivate their purchase intention and their disposition towards high prices to increase their status within society (Valae \& Nikhashemi, 2017).

Another key finding of our paper is the noticeable effect subjective norm has on purchase intention which resembles numerous prior studies (Choo et al., 2012; Ramayah et al., 2010; Gao et al., 2009). Moreover, the findings reveal that subjective norm's effect on consumers' disposition towards premium price is intense. This result shows that the social factor will motivate consumers to request a product as well as encourage their satisfaction with premium price, even if a cheaper price is available. It matches Chaudhary's (2018) results which noted that clients content with high prices will have the intention to buy green products in the Indian market which confirm the strong impact of the social factor on consumers' decisions and consequently, their buying behaviour (Bartels \& Hoogendam, 2011).

At last, the results show that purchase intention has a noticeable effect on contentment with premium price. Previous studies show that consumers' intention to purchase an item from a particular brand will lead to future purchase (Hsu et al., 2015), and that brand loyalty will lead to repeated buying behaviour (Chiu \& Leng, 2016). Customers with the intention to buy luxury products will end up paying the high price, even in the case of an increase in price overtime.

\section{Implication}

\subsection{Theoretical Implications}

Our research has created a conceptual model explaining the cause and effect of purchase intention behaviour regarding luxury fashion products in Malaysia. Specifically, it integrates the variables of selfidentity and price premium into the TPB to provide a valuable insight into previously existing knowledge. Our findings provide numerous contributions to literature dealing with marketing-based themes. 
Foremost is that current research demonstrates the outcome of self-identity on individuals' decisions and explains that consumers have a strong motivation to buy luxury products when those products reflect their image and match one of their characteristics.

Secondly, this study examines the impact of clients' desire to buy luxury fashion, their attitude as well as their subjective norm on their contentment with premium price. Examining the relationship between these variables will help us further understand the factors that will encourage customer disposition towards premium price.

\subsection{Practical Implications}

This study defines the categories of market segmentation in more detail, highlighting the psychological characteristics of Malaysian clients interested in luxury items which lead them to behave in line with their purchase intention, even when the products are sold at premium price. In addition, psychological values like age, gender and income effectively segment wealthy consumers.

The strong relationship between subjective norm and purchase intention, along with disposition towards premium prices, support the development of marketing strategies for luxury fashion brands in Malaysia to achieve a higher position and to communicate with the targeted consumers. In Malaysia, providing a superior products strategy may not be enough for a marketer to give their product an advantage. Instead they will need to consider shifting their focus to developing effective approaches that will help consumers meet their social goals. Furthermore, marketers will need to focus on the social meaning of their products and be able to express in what way their products will be beneficial to customers in a way that reflects their social status in society.

As self-identity is found to have the strongest impact on consumers' attitude, it is advised that marketers differentiate their products within their brand. In other words, marketers must show how different product lines reflect characteristics of an individual's image. Marketers may consider the customization strategy with regards to product design so that consumers have further options of expressing their personality.

\subsection{Limitations and Direction for Future Research}

Although contributing to both practical and theoretical knowledge, the research method has several limitations that future studies will need to deal with. Intrinsically, subsequent research should evaluate the model in various cultures, societies and different industries. Secondly, subsequent research should consider gender, age and income as moderators of the relationship between self-identity and other elements in the model. Thirdly, since the predicting power of purchase intention and price premium is about $69 \%$, which means that there was a $31 \%$ unexplained variance. Thus, for the benefit of future research, qualitative research is recommended to explore new variables that will increase the percent variance of the purchase behaviour construct.

\section{References}

Adler, N. J. (1983). A typology of management studies involving culture. Journal of International Business Studies, 14(2), 29-47.

Ailawadi, K. L., Lehmann, D. R., \& Neslin, S. A. (2003). Revenue premium as an outcome measure of brand equity. Journal of Marketing, 67(4), 1-17.

Ajzen, I. (1985). From Intentions to Actions: A Theory of Planned Behavior. In J. Kuhl \& J. Beckmann (Eds.), Action Control (pp. 11-39). Berlin, Heidelberg: Springer Berlin Heidelberg. https://doi.org/10.1007/978-3-642-69746-3_2

Ajzen, I. (1991). The theory of planned behavior. Organizational Behavior and Human Decision Processes, 50(2), 179-211. https://doi.org/http://dx.doi.org/10.1016/0749-5978(91)90020-T

Ajzen, I., \& Fishbein, M. (1980). Understanding attitudes and predicting social behaviour. PrenticeHall. 
Anderson, J. C., \& Gerbing, D. W. (1982). Some methods for respecifying measurement models to obtain unidimensional construct measurement. Journal of Marketing Research, 453-460.

Anselmsson, J., Vestman Bondesson, N., \& Johansson, U. (2014). Brand image and customers' willingness to pay a price premium for food brands. Journal of Product \& Brand Management, 23(2), 90-102. https://doi.org/10.1108/JPBM-10-2013-0414

Ashraf, S. (2017). Do They Care What They Believe ? Exploring the Impact of Religiosity on Intention to Purchase Luxury Products. Pakistan Journal of Commerce and Social Sciences, 11(2), 428-447.

Bagozzi, R. P., Yi, Y., \& Phillips, L. W. (1991). Assessing construct validity in organizational research. Administrative Science Quarterly, 421-458.

Bang, H., Ellinger, A. E., Hadjimarcou, J., \& Traichal, P. A. (2000). Consumer concern, knowledge, belief, and attitude toward renewable energy: An application of the reasoned action theory. Psychology \{\&\} Marketing, 17(6), 449-468.

Bartels, J., \& Hoogendam, K. (2011). The role of social identity and attitudes toward sustainability brands in buying behaviors for organic products. Journal of Brand Management, 18(9), 697-708. https://doi.org/10.1057/bm.2011.3

Berthon, P., Pitt, L., Parent, M., \& Berthon, J.-P. (2009). Aesthetics and Ephemerality: Observing and Preserving the Luxury Brand. California Management Review, 52(1), 45-66.

Bryman, A., \& Bell, E. (2007). Business research Methods 2nd Ed Oxford University press.

Chaudhary, R. (2018). Green buying behavior in India: an empirical analysis. Journal of Global Responsibility, 9(2), 179-192. https://doi.org/10.1108/JGR-12-2017-0058

Cheah, I., Phau, I., Chong, C., \& Shimul, A. S. (2015). Antecedents and outcomes of brand prominence on willingness to buy luxury brands. Journal of Fashion Marketing and Management: An International Journal, 19(4), 402-415. https://doi.org/10.1108/JFMM-03-2015-0028

Chen, M.-F., \& Tung, P.-J. (2014). Developing an extended Theory of Planned Behavior model to predict consumers' intention to visit green hotels. International Journal of Hospitality Management, 36, 221230. https://doi.org/http://doi.org/10.1016/j.ijhm.2013.09.006

Chiu, W., \& Leng, H. K. (2016). Consumers' intention to purchase counterfeit sporting goods in Singapore and Taiwan. Asia Pacific Journal of Marketing and Logistics, 28(1), 23-36. https://doi.org/10.1108/APJML-02-2015-0031

Choo, H. J., Moon, H., Kim, H., \& Yoon, N. (2012). Luxury customer value. Journal of Fashion Marketing and Management, 16(1), 81-101. https://doi.org/10.1108/13612021211203041

Coelho, P. S., Rita, P., \& Santos, Z. R. (2018). On the relationship between consumer-brand identification, brand community, and brand loyalty. Journal of Retailing and Consumer Services, 43(November 2016), 101-110. https://doi.org/10.1016/j.jretconser.2018.03.011

De Mooij, M. (2010). Consumer behavior and culture: Consequences for global marketing and advertising. Thousand Oaks, CA.: Sage Publications.

Department of Statistics Malaysia. (2016). Department of Statistics Malaysia Official Portal.

Euromonitor International. (2016). Luxury Goods in Malaysia. Retrieved from http://www.euromonitor.com/luxury-goods-in-malaysia/report

Fitzmaurice, J. (2005). Incorporating consumers' motivations into the theory of reasoned action. Psychology and Marketing, 22(11), 911-929. https://doi.org/10.1002/mar.20090

Fornell, C., \& Larcker, D. F. (1981). Evaluating structural equation models with unobservable variables and measurement error. Journal of Marketing Research, 18(1), 39-50.

Gao, L., Norton, M. J. T., \& Chester, Z. Z. (2009). Potential niche markets for luxury fashion goods in China. Journal of Fashion Marketing and Management. https://doi.org/10.1108/13612020910991376

Ha, H.-Y., \& Janda, S. (2012). Predicting consumer intentions to purchase energy-efficient products. Journal of Consumer Marketing, 29(7), 461-469.

Hair, J. F., Ringle, C. M., \& Sarstedt, M. (2011). PLS-SEM: Indeed a silver bullet. The Journal of Marketing Theory and Practice, 19(2), 139-152.

Hair Jr, J. F., Hult, G. T. M., Ringle, C., \& Sarstedt, M. (2016). A primer on partial least squares structural equation modeling (PLS-SEM). Sage Publications.

Han, T., \& Stoel, L. (2016). The effect of social norms and product knowledge on purchase of organic 
cotton and fair-trade apparel. Journal of Global Fashion Marketing, 7(2), 89-102. https://doi.org/10.1080/20932685.2015.1131434

Harman, H. H. (1976). Modern factor analysis. Chicago, IL: University of Chicago Press.

Heine, K. (2010). The Personality of Luxury Fashion Brands. Journal of Global Fashion Marketing, 1(3), 154-163. https://doi.org/10.1080/20932685.2010.10593067

Henseler, J. (2010). On the convergence of the partial least squares path modeling algorithm. Computational Statistics, 25(1), 107-120.

Henseler, J., Dijkstra, T. K., Sarstedt, M., Ringle, C. M., Diamantopoulos, A., Straub, D. W., ... Calantone, R. J. (2014). Common beliefs and reality about PLS: Comments on Rönkkö and Evermann (2013). Organizational Research Methods, 17(2), 182-209.

Henseler, J., Ringle, C. M., \& Sarstedt, M. (2015). A new criterion for assessing discriminant validity in variance-based structural equation modeling. Journal of the Academy of Marketing Science, 43(1), $115-135$.

Hsu, C. L., Chang, C. Y., \& Yansritakul, C. (2017). Exploring purchase intention of green skincare products using the theory of planned behavior: Testing the moderating effects of country of origin and price sensitivity. Journal of Retailing and Consumer Services, 34, 145-152. https://doi.org/10.1016/j.jretconser.2016.10.006

Hsu, M., Chang, C., \& Chuang, L. (2015). Understanding the determinants of online repeat purchase intention and moderating role of habit: The case of online group-buying in Taiwan. International Journal of Information Management, 35(1), 45-56. https://doi.org/10.1016/j.ijinfomgt.2014.09.002

Hultman, M., Kazeminia, A., \& Ghasemi, V. (2015). Intention to visit and willingness to pay premium for ecotourism : The impact of attitude, materialism, and motivation. Journal of Business Research, 68(9), 1854-1861. https://doi.org/10.1016/j.jbusres.2015.01.013

Hustvedt, G., \& Dickson, M. A. (2008). Consumer likelihood of purchasing organic cotton apparel Influence of attitudes and self-identity. Journal of Fashion Marketing and Management, 49-65. https://doi.org/10.1108/13612020910939879

Jain, S., \& Khan, M. N. (2017). Measuring the impact of beliefs on luxury buying behavior in an emerging market. Journal of Fashion Marketing and Management: An International Journal, 21(3), 341-360. https://doi.org/10.1108/JFMM-07-2016-0065

Kapferer, J. N., \& Laurent, G. (2016). Where do consumers think luxury begins? A study of perceived minimum price for 21 luxury goods in 7 countries. Journal of Business Research, 69(1), 332-340. https://doi.org/10.1016/j.jbusres.2015.08.005

Kauppinen-Räisänen, H., Gummerus, J., Koskull, C. von, Finne, A., Helkkula, A., Kowalkowski, C., \& Rindell, A. (2014). Am I worth it? Gifting myself with luxury. Journal of Fashion Marketing and Management, 18(2), 112-132.

Keller, K. L., \& Kotler, P. (2016). Marketing management. Pearson.

Khallouli, K. J., \& Gharbi, A. (2013). Symbolic consumption by teenagers: a discussion through the optics of appearance and identity. International Journal of Business and Social Science, 4(7), 99-105.

Kong, H. M., \& Ko, E. (2017). Why do consumers choose sustainable fashion ? A cross-cultural study of South Korean, Chinese , and Japanese consumers. Journal of Global Fashion Marketing, 8(3), 220-234. https://doi.org/10.1080/20932685.2017.1336458

Li, N., Robson, A., \& Coates, N. (2013). Chinese consumers' purchasing: impact of value and affect. Journal of Fashion Marketing and Management, 17(4), 486-508.

Loureiro, S. M. C., \& Araújo, C. M. B. de. (2014). Luxury values and experience as drivers for consumers to recommend and pay more. Journal of Retailing and Consumer Services, 21(3), 394-400. https://doi.org/10.1016/j.jretconser.2013.11.007

MacKenzie, S. B., \& Podsakoff, P. M. (2012). Common method bias in marketing: causes, mechanisms, and procedural remedies. Journal of Retailing, 88(4), 542-555.

Madden, T. J., Ellen, P. S., \& Ajzen, I. (1992). A Comparison of the Theory of Planned Behavior and the Theory of Reasoned Action. Personality and Social Psychology Bulletin, 18(1), 3-9. https://doi.org/10.1177/0146167292181001

Maloney, J., Lee, M., Jackson, V., Maloney, J., Lee, M., Jackson, V., ... Miller-spillman, K. A. (2014). 
Consumer willingness to purchase organic products : Application of the theory of planned behavior. Journal of Global Fashion Marketing, 5(4), 308-321. https://doi.org/10.1080/20932685.2014.925327

Mamat, M. N., Noor, N. M., \& Noor, N. M. (2016). Purchase intentions of foreign luxury brand handbags among consumers in Kuala Lumpur, Malaysia. In Procedia Economics and Finance (Vol. 35, pp. 206-215). Elsevier B.V. https://doi.org/10.1016/S2212-5671(16)00026-5

Maria, A., \& Brandão, C. (2017). The impact of brand love in building brand loyalty among young consumers by Master Dissertation in Marketing Advisor : THESIS.

McColl, J., \& Moore, C. (2011). An exploration of fashion retailer own brand strategies. Journal of Fashion Marketing and Management: An International Journal, 15(1), 91-107.

Michaelidou, N., \& Dibb, S. (2006). Extending the technology acceptance model to mobile telecommunication innovation: The existence of network externalities. Journal of Consumer Behaviour, 5(5), 442-453. https://doi.org/10.1002/cb

Nueno, J. L., \& Quelch, J. A. (1998). The mass marketing of luxury. Business Horizons, 41(6), 61-68.

Ramayah, T., Ahmad, N. H., \& Lo, M.-C. (2010). The role of quality factors in intention to continue using an e-learning system in Malaysia. Procedia - Social and Behavioral Sciences, 2(2), 5422-5426. https://doi.org/10.1016/j.sbspro.2010.03.885

Reinartz, W., Haenlein, M., \& Henseler, J. (2009). An empirical comparison of the efficacy of covariance-based and variance-based SEM. International Journal of Research in Marketing, 26(4), $332-344$.

Rezaei, S. (2015). Segmenting consumer decision-making styles (CDMS) toward marketing practice: A partial least squares (PLS) path modeling approach. Journal of Retailing and Consumer Services, 22, $1-15$.

Ringle, C. M., Sarstedt, M., \& Straub, D. W. (2012). A Critical Look at the Use of PLS-SEM in MIS Quarterly. MIS Quarterly(MISQ), 36(1).

Schade, M., Hegner, S., Horstmann, F., \& Brinkmann, N. (2016). The impact of attitude functions on luxury brand consumption: An age-based group comparison. Journal of Business Research, 69(1), 314-322. https://doi.org/10.1016/j.jbusres.2015.08.003

Sekaran, U. (2006). Research Methods for Business: A Skill Building Approach. Willey.

Shin, Y. H., Hancer, M., \& Song, J. H. (2016). Self-Congruity and the Theory of Planned Behavior in the Prediction of Local Food Purchase. Journal of International Food \& Agribusiness Marketing, 28(4), 330-345. https://doi.org/10.1080/08974438.2016.1145612

Shukla, P., Shukla, E., \& Sharma, S. (2009). Conspicuous Consumption in Cross-national Context: Psychological and Brand Antecedents. Association for Consumer Research, Asia-Pacific Advances, $8,16-19$.

Singh, \& Sanjay, K. (2009). Understanding cultural architectures of organisations in India: a study. Singapore Management Review, 31(2), 71-95.

Sirgy, M. J. (1986). Self-congruity: Toward a theory of personality and cybernetics. Praeger Publishers/Greenwood Publishing Group.

Sirgy, M. J., Johar, J. S., Samli, A. C., \& Claiborne, C. B. (1991). Self-congruity versus functional congruity: Predictors of consumer behavior. Journal of the Academy of Marketing Science, 19(4), $363-375$.

Sjostrom, T., Corsi, A. M., \& Lockshin, L. (2016). What characterises luxury products? A study across three product categories. International Journal of Wine Business Research, 28(1), 76-95.

Soh, C. Q. Y., Rezaei, S., \& Gu, M.-L. (2017). A structural model of the antecedents and consequences of Generation Y luxury fashion goods purchase decisions. Young Consumers, 18(2), 180-204. https://doi.org/10.1108/YC-12-2016-00654

Spector, P. E. (2006). Method variance in organizational research: truth or urban legend? Organizational Research Methods, 9(2), 221-232.

Stall-meadows, C., \& Davey, A. (2015). Green marketing of apparel : consumers ' price sensitivity to environmental marketing claims. Journal of Global Fashion Marketing, 4(1), 37-41. https://doi.org/10.1080/20932685.2012.753293

Statpac. (2014). Survay sampling methods. Retrieved November 12, 2016, from 
https://www.statpac.com/surveys/sampling.htm

Timperio, G., Tan, K. C., Fratocchi, L., \& Pace, S. (2016). The impact of ethnicity on luxury perception: the case of Singapore's Generation Y. Asia Pacific Journal of Marketing and Logistics, 28(2), 217 233. https://doi.org/10.1108/APJML-04-2015-0060

Valae, N., \& Nikhashemi, S. R. (2017). Generation Y consumers ' buying behaviour in fashion apparel industry : a moderation analysis. Journal of Fashion Marketing and Management: An International Journal, 21(4), 523-543. https://doi.org/10.1108/JFMM-01-2017-0002

Vigneron, F., \& Johnson, L. W. (2004). Measuring perceptions of brand luxury. The Journal of Brand Management, 11(6), 484-506.

Vijaranakorn, K., \& Shannon, R. (2017). The influence of country image on luxury value perception and purchase intention. Journal of Asia Business Studies, 11(1), 88-110. https://doi.org/10.1108/JABS08-2015-0142

Westland, J. C. (2010). Lower bounds on sample size in structural equation modeling. Electronic Commerce Research and Applications, 9(6), 476-487.

Wiedmann, K. P., Hennigs, N., \& Siebels, A. (2009). Value-Based Segmentation of Luxury Consumption Behavior. Psychology \& Marketing, 26(7), 625-651. https://doi.org/10.1002/mar

Wu, M.-S. S., Chaney, I., Chen, C.-H. S., Nguyen, B., \& Melewar, T. C. (2015). luxury fashion brands, factor influencing young female consumers' luxury fashion purcasing in Taiwan. Qualitative Market Research: An International Journal, 18(3), 298-319. https://doi.org/http://dx.doi.org/10.1108/QMR02-2014-0016

Wu, M.-S. S., Chen, C.-H. S., \& Nguyen, B. (2015). Luxury brand purchases and the extended self: a cross-cultural comparison of young female consumers in Taiwan and the UK. Asia-Pacific Journal of Business Administration, 7(3), 153-173.

Zhan, L., \& He, Y. (2012). Understanding luxury consumption in China: Consumer perceptions of bestknown brands. Journal of Business Research, 65(10), 1452-1460. https://doi.org/10.1016/j.jbusres.2011.10.011

Zhang, B., \& Kim, J.-H. (2013). Luxury fashion consumption in China: Factors affecting attitude and purchase intent. Journal of Retailing and Consumer Services, 20(1), 68-79.

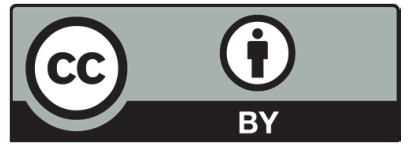

(C) 2018 by the authors; licensee Growing Science, Canada. This is an open access article distributed under the terms and conditions of the Creative Commons Attribution (CCBY) license (http://creativecommons.org/licenses/by/4.0/). 